\author{
Antiie Krog \\ Antjie Krog is Professor in the Faculty \\ of Arts at the University of the \\ Western Cape. Much of her work \\ focus on translation and South African \\ languages other than English. \\ Email: akrog@uwc.ac.za
}

\section{'... oi, oi! ... you must go by the right path': Mofolo's Chaka revisited via the original text}

\title{
'... oi, oi! ... you must go by the right path': Mofolo's Chaka revisited via the original text
}

Thomas Mofolo never defended himself against accusations that his novel Chaka distorts historical facts to express anti-Nguni sentiments under the guise of Christianity. But in a way he foreshadowed the possibility of it, by including as part of his novel a sentence which has become one of his most analysed: "But since it is not our purpose to recount all the affairs of his [Chaka's] life, we have chosen only one part which suits our present purpose". Mofolo does not elaborate on what he means by "our present purpose", but simply continues with the story. By focusing on the original Sesotho text, indigenous Zulu customs, African philosophy and the diversions from historical facts, this article explores other possibilities for what could have been Mofolo's "present purpose". My reading is that he tries to plumb what comprises ethical behaviour within a traditionally-valued, pre-Christian ethos, making Chaka arguably one of the earliest philosophical, ethical investigations via the form of the novel on the African continent. Keywords: African philosophy, Chaka, interconnectedness, Thomas Mofolo, translation.

Daniel Kunene is in no doubt that Mofolo's book on Chaka is decisively influenced by Christian values. Although he concedes that the novel is much less of a "sermon" or a "propagation of the Gospel" than Mofolo's two previous novels-Moeti oa bochabela and Pitseng-he states that "when Mofolo speaks of sin in this book [Chaka], we know that he is speaking of $\sin$ in the Christian sense, and not of social sin in the context of the social milieu which constitutes the setting for his story" ("Works of Thomas Mofolo" 16).

Kunene's insistence that Christian values dominate the novel has not only been accepted by several subsequent scholars, but was the primary demand from the missionaries themselves during the time of publication in Lesotho in 1925. An upset Ellenberger described the book as nothing but an apology for pagan superstitions. "It is strange that a religious establishment like our mission published such a book; it should not be permitted that the literary value of a work makes us forget the pernicious effects it can have." He regarded Chaka as an "evil book" (qtd. in Gérard 129).

Gérard suggests that "[f]ew African works exhibit such a profoundly integrated sense of the meaning of freedom and guilt in Christian ethics" as Mofolo's novel Chaka (125). In similar vein Attwell suggests that Chaka was produced through "scriptural tradition" (61), and makes references of the main character's flight into the desert 
and subsequent temptation. "Chaka constitutes a Christian—specifically missionorientated and Protestant-intervention into the ideological domain of emergent black nationalist political life in South Africa" (52).

Looking at the legacy of Mofolo's Chaka, Mbongeni Malaba also sees the novel as being drenched in Christian imagery. He refers to Mofolo's "memorable portrayal of the hellish trinity: Isanusi, Ndlebe and Malunga, a triumvirate that appears in other, derivative, literature-notably in the Chakan drama written by Francophone African writers. Isanusi epitomises Satanic guile, cloaking his malice with sweet reasonableness" (61).

The word "evil" also features in Kunene. After identifying Mofolo's "distortion" of Sekese's facts (Azariel Sekese published informative articles on Chaka in Leselinyana la Lesotho (Kunene, Thomas Mofolo 165) Kunene says: "On balance, then, one cannot escape the conclusion that Mofolo's intention as he selected his facts or interpreted them or created new fictitious episodes which did not happen in Chaka's life, was to project him as the embodiment of pure evil, a villain with no redeeming feature whatsoever. The question is why?" (172).

In his conclusion about Mofolo's purpose in writing the novel, Kunene formulates it even more strongly:

Mofolo's unspecified 'purpose in writing this book' was to represent Chaka as a totally depraved person, at best without any redeeming features, the "originator-of-all-thingsevil". One cannot resist yet another 'Why?'. There are three reasons, it seems to me. The first one has already been mentioned namely Mofolo's apparent anti-Nguni sentiment. The second one is that his Christian conscience was probably so outraged by Chaka's excesses that he saw him, and wanted to portray him, as a devil, and devils don't have virtues. Thirdly, Mofolo's treatment accords well with the general depiction of good and evil in African language novels and novelettes in southern Africa. Characters are all too often projected as either totally good or totally evil, in other words, as either saints or devils, never quite as human beings who necessarily combine these two extremes. (Thomas Mofolo 174)

Kunene identifies a few instances which for him illustrate perfectly how Mofolo's deviation from the known facts can only be ascribed to obeisance to Christian values and sentiments. Regarding the first chapter when Senzangakhona (as "traditional African") organises a feast where, attracted to Nandi, he pushes his desire to "disregard the restraints of custom", Kunene says:

And out of this rather untidy mess, he gets his long-desired son and heir, Chaka. This is where the Christian morality is introduced, and the concept of sin begins to be a factor in Mofolo's attitude to his characters. First of all, in pursuing his 'purpose', Mofolo makes the encounter between Nandi and Senzangakhona in the fields a matter of Christian moral judgement, and the latter (Senzangakhona) emerges from the scene 
tainted by his lack of restraint, and fitting the label of sinner later applied to him. It is understandable then, that Chaka, the fruit of sin, should be overtaken by the wrath of God and made to suffer, for the sins of the father shall be visited upon the son.

(Thomas Mofolo 110)

For Kunene Mofolo did two things: he accepted tradition, but then, "the Christian element in Mofolo asserts itself at the same moment that Senzangakhona oversteps the bounds of both the traditional and Christian values. At this point, however, Mofolo ignores the traditional mechanisms for handling the problem of extra-marital impregnation, and, by applying Christian standards, blows the whole question out of proportion" (Thomas Mofolo 111). "Soon Nandi and Chaka fall out of favour", says Kunene, and "[t]here is a general sentiment that Chaka is a child of evil, and ought to be destroyed" (Thomas Mofolo 110-1).

Thus Kunene. To unpack his argument, it is important to bear in mind that translation goes hand in hand with a kind of pre-interpretation whenever it deals with issues of culture. Gideon Toury warns about the imperceptibility of the process of translation: "Translated texts and their constitutive elements are observational facts, directly accessible to the eye. In contrast, translating processes, i.e. those series of operations whereby actual translations are derived from actual source texts [...] are only indirectly available for study, as they are the kind of 'black box' whose internal structure can only be guessed, or tentatively reconstructed" (qtd. in Hermans 18).

So we can only guess at the processes Kunene had to work through when he was translating the rendering of Zulu culture in Sesotho (source language-SL) into English (target language-TL). North American anthropologist Michael Agar suggests that "culture is not something that people have; it is something that fills the spaces between them", and that these cultural boundaries are marked by "rich points": "... some things that come up strike you with their difficulty, their complexity, their inability to fit into the resources you use to make sense of the world. These things-from lexical items through speech acts up to fundamental notions of how the world works-are called rich points" (168).

I am arguing that Kunene faced several "rich points" when he was translating Mofolo and never more so than when he had to translate culturally embedded words like botho, motho, mobe, kgopo, sebe and so on. His arguments for the heavy influence of Christianity make good sense when only the English version is considered. However, when the original text is revisited, it becomes possible to come to a set of different interpretative judgements.

From the outset in English Senzangakhona's seduction of Nandi (Mofolo 5) is rendered in "ugly" and "evil" terms: the king persuaded Nandi that the two of them should do "an ugly deed"; the girls were persuaded to participate in Senzangakhona's "evil scheme"; and when Nandi finally "bowed her head [...] Senzangakhona 
accomplished the evil design of his heart". And later: Senzangakhona wished that "Chaka should be killed for he was a child of sin". This indeed calls forth Christian notions of sin, evil and punishment. Kunene further reproaches Mofolo for not allowing tradition to take its course to deal with impregnation out of wedlock and suggests that it was Mofolo's overriding Christian attitude which now rewrites Chaka's life as paying for the sins of the father.

But it seems that Mofolo's Sesotho text can also be read in a different way, especially where the culturally laden "rich points" are concerned. "Senzangakhona a pheella Nandi ka matla a maholo hore ba etse lisele, tse hanoang ke molao le ke thaho ea batho" is translated by Kunene as follows: "That day Senzangakhona used strong arguments to persuade Nandi that the two of them should do an ugly deed that was against the law of nature and of man." But with different choices the sentence could also have read: "That day Senzangakhona used strong arguments to persuade Nandi that the two of them should do something untoward /naughty that was not acceptable to people in general."

The following alternatives for the word lisele are given by Du Plessis, Gildenhuys and Moiloa in their Sesotho dictionary: other, foreign, strange, different. In the interview with Njabulo Ndebele, he translates lisele as "naughty" or "silly". To compare, in the paragraph about the first radical change in Chaka, Mofolo says: " $o$ khutla ka moea osele le ka botho bosele"; this is translated by Kunene as: "comes back with a completely different spirit and a different personality" (Mofolo 47). If the translation was a "strange/different/foreign deed" instead of "ugly", it would have greatly lessened the puritan Christian tone.

But even more so in the following: "utloa morero o mobe oa Senzangakhona" (listen to Senzangakhona's evil scheme) and "Senzangakhona a phetha morero o mobe oa pelo ea hae" (Senzangakhona accomplished the evil design of his heart). Mobe does not mean first and foremost evil. According to the dictionary $-b \bar{e}$ as an adjective means "bad", "ugly". So mobe could have been translated as "ill-intention", "something unacceptable", "not good", "ugly"; but by choosing the word "evil" a choice was made by the translator and not necessarily the writer-probably precisely because of the difficulty, the complexity, the inability of these concepts to fit neatly into the English resources Kunene had to use.

Mofolo is also given no credit for the ways in which he had Senzangakhona indeed use traditional ways after Nandi's pregnancy became known: Senzangakhona immediately made arrangements to marry Nandi; he sent fifty five cattle to her parents; told his chief Jobe that a son was born; and sent a whole range of animals to Nandi's homestead. In her book on Zulu custom Harriet Ngubane discusses the tradition around a newly born: "Each child is placed under the protection of the ancestors by a sacrifice of a goat known as imbeleko (beleka, vb., to carry on the back.) [...] It is a form of 'baptism' which puts the baby under the protection of a definite range of 
ancestors" (51-2). Animals were also sent after Chaka had been weaned so that the text specifically mentions how chubby and bouncing Chaka was. It was only when Senzangakhona's other wives bore sons and threatened both him and Nandi with witchcraft that the restored relationship fell apart.

Even if one looks at the traditional aspect of handling some of the other situations, Mofolo cannot be faulted. Ngubane says that young unmarried girls are organised in age-groups. "If one of them becomes pregnant before marriage, this is considered a problematic 'precedent' which mystically endangers her age-mates". It is considered as having "opened the way for further misfortunes" and this is expressed in the term umkhokha (80). It is clear that Senzangakhona knew that a baby was protected by the patrilineal line of its paternal grandfather's ancestors (Ngubane 52), and took steps to influence the consequences through livestock.

I do not mean to suggest that subliminal Christian sentiments are completely absent in Mofolo's Chaka, but want to explore the possibility that in his novel he was systematically and coherently exploring a particular thread of African philosophy within leadership.

After the young Chaka had been blessed by the King of the Deep Pool, he was covered in mist, heard a booming stentorian voice and then a soft voice. This soft voice was only heard by him, saying: "And all things shall obey you with unquestioning obedience, and shall kneel at your feet! O yes, oi! oi! Yet you must go by the right path" (24).

What is this right path? Is Mofolo forcing a Christian righteousness into the story or is he suggesting "a right path" within the traditional context of the story? Gabriel Setiloane, Professor in Religious Studies before his death, describes "that greatest of all evils according to African Traditional Religion [is]: careless disregard for others" (qtd. in Brand 98, my emphasis). The right path is: regard for others. Wrongdoing is described by Keith Fernado (qtd. Brand 83) as follows:

sin in many African cultures is defined not so much in terms of the nature of the act itself, but rather its consequences [...] Thus to say that "sin" disrupts harmony and causes suffering is tautologous [...] An act that disrupts the harmony of the cosmos in a way harmful to the interests of man is ipso facto evil: if no harmful consequences are entailed it is therefore probably inaccurate to speak in terms of "offence" or "sin".

It is an important concept to bear in mind-sexual intercourse before marriage was therefore not necessarily a "sin" which would validate a translation of "ugly' instead of "an untoward/naughty deed" - but it is the consequences of the sexual intercourse that would in the end determine whether the deed was wrong. We see in the story that through the use of traditional customs Senzangakhona tried to restore the equilibrium. He seemed to have succeeded until the first son was born from the other wives. The disruption and repercussions from the community around the other wives 
turned the "silly deed" into sin, but sin in an African traditional sense and actually now not committed by the two lovers, but by the envious wives.

Ngubane confirms the importance of equilibrium and harmony: "A Zulu conceives good health not only as consisting of a healthy body, but as a healthy situation of everything that concerns him. Good health means the harmonious working and coordination of this universe" (27-8). According to her there is no word in Zulu which means "balance". The notion is implied in the word lungisa (vb. lunga): "to put in order, arrange, adjust, set as it should be, tidy, or hlela, or uhlelo; ukuzilungisa, meaning moral order, a symmetrical sense of relation" (27). In order to survive, everyone must establish and maintain a form of balance with his surroundings. The balance is established not only between a man and his impersonal surroundings, but also between man and man (26).

In order to achieve balance as well as protection, the help of a variety of healers or diviners was often sought. Berglund identifies four groups of diviners, among them two that specifically protect lineage (306-12). Ngubane also talks about a lineage sorcerer (uzalo) who can persuade an ancestor to favour a particular person (36). In other words, diviners and also witchcraft are used on people who begin to carelessly disregard others and disrupt harmony.

The second important deviation from Sekese's facts, according to Kunene, is that Mofolo invents a character such as Isanusi specifically in order to lead the reader to condemn Chaka as totally depraved and evil. Kunene identifies the meeting with Isanusi as the pivotal moment in the novel.

Chaka's meeting with the Isanusi is symbolic of the continuing metamorphosis of his personality and general philosophy of life [...] This is the beginning of the real tragedy: Chaka responds as any human being in his situation would have done, by welcoming the stranger who seems to have the power to help him. Yet by that act he compromises himself. His acceptance of Isanusi is the beginning of a series of similar confrontations from which Chaka emerges with his human quality even more eroded than before. Thus Isanusi's oblique, guarded and insidious tactics in guiding Chaka towards identifying him, the indirect hints and clues, are all intended to put it squarely on Chaka's shoulders to decide for himself, through a process of elimination and deduction, that this is he, which in itself is a choice [...] [the scene] signals Mofolo's change of attitude towards Chaka. From this point on, Mofolo places the entire moral responsibility on Chaka, and never misses an opportunity to indict him for choosing the path of doom rather than the way of life [...] The fact that Isanusi then stands aside and leaves Chaka to "choose" cannot disguise the fact that Mofolo has created a climate where certain "choices" seem inevitable, while their alternative remain only remote and unattractive possibilities [...] a Scylla and Charybdis situation rather than an easy decision to follow the path of life or of death. (Thomas Mofolo 113-6, 166-7) 
Painting Chaka as a person of free will who deliberately makes his own individual evil choices, forms for Kunene part of Christian thinking and is for him proof that Mofolo specifically makes use of that in order to vent his anti-Nguni sentiments.

But what exactly is happening during the meeting itself? We have a highly gifted young man with a past filled with unfair and envious rejection and persecution. In front of him stands a powerful doctor saying: "Now tell me the desires of your heart, and the one thing on which, of all others, you want me to concentrate my skills." Chaka's first response is simple and modest: "I do not have many wishes. My heart yearns for the kingship for which I was born, which slips out of my hands simply because I have had bad luck. I say to you, work on me so that that kingship should be restored to me" (41). In other words, Chaka wants a restoration, a bringing back of a harmony or balance, ukuzilungisa, a return to the initial moral order, a symmetrical sense of relation with his surroundings as well as between him and his fellow clan men (Ngubane 26).

Now follows the crucial moment. Slightly sarcastically an incredulous Isanusi lures him: "I understand. All you want is your father's kingship, beyond that there is nothing you want, not even a kingship that surpasses that of your father. That is what you are saying, is that not so?" (41) and immediately Chaka is aware of far greater possibilities amply laid out in front of him. But, and it is a very important but, this is pulling the carpet from under the argument that Christianity is at work in Chaka's choice. In Christianity there is nothing wrong in personal ambition. In fact Kunene agrees: "Chaka immediately takes the cue and responds enthusiastically that, if there is a greater kingship than his father's, of course he wants it. [...] And, indeed, at this time there is nothing morally wrong in that choice" (Thomas Mofolo 123). Nothing morally wrong in a Christian sense, that is. But within African philosophy Chaka has just taken the most fatal step: a choice based purely on personal ambition, a choice disregarding others, wanting more than restoring balance: "No, I do want that. If you can make me into a great king [...] I shall be very grateful" (41). Now Chaka is filled with personal ambition; the concern about the normalisation of the power structures of a small clan counts for nothing. I am trying to point out that Kunene identifies the right moment of change, but that his argument that the "wrongness" of Chaka's behaviour afterwards lies within a Christian ethos put there by Mofolo can be debated. My reading is that, for Mofolo, the "wrongness" of the choice lies squarely within an African concept of sin as formulated by Setiloane: careless disregard of others.

And true enough, Isanusi's first instructions confirm this: "If you like kingship and fame, you must be like that. You must be a cultivator of kingship: Let your spear be your hoe, use it, and use it intelligently. Where necessary you must reduce everything to total annihilation, sweep it all away" (46-7). A second lesson follows: "[...] and now you too must part with mercy from this very day, because mercy devours its owner" (41). 
The effect of this deliberate disregard for morality has an immediately dehumanising effect on Chaka:

[...] the day he left home in flight, he left as Chaka, a human being like all other human beings who had human failings. Today he comes back greatly changed; it is only his flesh that is coming back, only his outer self; as for his true self, that has remained at the place from which he is returning; he comes back with a completely different spirit and a different personality [...] Indeed, Chaka returns [from Isanusi] with no human feeling left in him, his sole aim being to kill [...] the frightening vengeance in his heart is indeed about to drive him mad. $(47-8)$

Interestingly enough, a state like this, using the same concept as Mofolo of two living parts within one human being, of which one is dead, had been recorded among the Batswana describing people who live only for themselves: "The light of the mind is darkened and [his] character deteriorates, so that it may be said that the real manhood is dead, though the body still lives; when they realise that to all intents and purposes the human being is alienated from fellowship with his kith and kin" (Brown qtd. in Comaroff and Comaroff 143).

Isanusi's instructions lead him further down this dehumanising path: "If you seek the fame for which you are crying, let that spear remain covered with blood, fresh blood, not dried up" (80). Mofolo's text is littered with the word botho, humanity. Every terrible deed by Chaka is contrasted with the deeds of those such as Noliwa and Dingiswayo who try to instil a spirit of botho. When he was fleeing as a terrified boy, Dingiswayo gave him asylum and "made him a human being again, tried to instil in his people a human compassion" (85). Noliwa is used as the embodiment of botho.

According to Limakatso Chaka (73) the word motho meaning "a person, a human being" is derived from the nominal form botho referring, on the one hand, to the state of being human "in appearance" and "knowing how to speak"; on the other hand, the cultural reference is obtained through a shift in meaning to signify the state of being not just a human being, but a person with humanity. In this sense, a person becomes motho (pl: batho) by accomplishing visible acts of compassion towards members of the society and outsiders. The cultural meaning of motho refers to a compassionate, kindhearted person who treats others with humanity, "regard".

Although Chaka's deeds initially have many positive spinoffs for his people, such as building a city, a nation, an impressive army and so on, he finds that he has to kill regularly and physically with his own spear to get rid of the depression and lack of feeling he experiences. After killings around his palace of ordinary followers, Mofolo says of Chaka: "And now his heart began to feel happy, and things begin to look normal again .... He could taste his food again ... and he felt like a human being again" (156). In this case motho (like the word botho) is one of those "rich points" 
Agar is talking about. In this context the word motho is much more and much less than a human being: it is motho without botho; a human being without being human.

Steadily Chaka's killings grow out of all control and logic, but in terms of the concept of an African worldview it is worthwhile noticing which killing is the last one that Chaka does before he is killed. In masterful passages Chaka's final decline echoes an enraged and anguished King Lear, a Macbeth drenched in blood and ambition, and a cold and cynical Faust. He becomes desensitised and unable to see beauty (the young, shiny skins of his wives seem full of pimples and scratches), and suspecting witchcraft he moves out of his city. According to Laurenti Magesa, one of witchcraft's main functions is to warn the individual that he should care for those around him: "Witchcraft is, in essence, a personal failure to keep destructive emotions in rein $[\ldots]$ witchcraft constantly warns individuals, through the community, against meanness, inhospitableness, rudeness, sullenness, disloyalty, false or reckless speech, and disrespect towards elders" (qtd. in Brand 94). Outside in the veld Chaka has visions and nightmares in which all those whom he had killed return to look at him; when he awakes sweating and shuddering in the night he hears a jackal cry "in pursuit of him", a hyena screamed "penetrating his heart", and a dog howls accusing him of killing its owners. Among his closest friends in the night he walks agitatedly up and down: "water boiling furiously in his stomach. His eyes sank deep in their sockets, receding far to the back; and sometimes they bulged out and drooped like those of a drunkard whose lungs had been consumed by liquor [...] His head swam and countless images flitted through his mind. [...] [H]e resembled a horse suffering from intestinal fever [...] running and biting itself, tearing the flesh from its body with its own teeth" (160). It is said repeatedly that his soul is in unbearable pain: "The pain woke him up. He tried to stand up, but was unable to do so. He tried to scream, but his mouth was stilled. Something pressed him to the ground. [...] finally [he] heaved himself up and reached for his spear. He stood on his feet, and threw glances this way and that, but he found that there was perfect stillness" (162).

Then Chaka sends two regiments out with false instructions so that they end up killing each other. Mofolo says: "That is to say [...] Chaka killed Zulus by Zulus, without them being aware of it" (162). And that seals Chaka's fate: Zulu against Zulu, without knowing. A few paragraphs later, Dingana and Mhlangana arrive to kill him.

\section{Conclusion}

Let me make it clear: Daniel Kunene's translation of Chaka produced a brilliant text and has enchanted many readers across the world. My endeavour here is merely to interrogate the widely held scholarly assumptions of the role of Christian values in the novel. Mofolo wrote two novels before this masterpiece. Both these novels are somewhat didactic and pervaded by a kind of conservative Christianity that was clearly expected by the missionaries and newspaper where he worked. My hypothesis 
is that, after these two books, Mofolo felt at the height of his creative powers, and confidently and deliberately chose a period over which the missionaries could have no say. Exploring the life of Chaka allowed Mofolo to move away from the mission Christianity into philosophy by ethically exploring African humanism.

According to Limakatso Chaka's essay, humanism or botho is anyway thoroughly explored in Mofolo's previous novels, but then as an integral part of Christianity: as botho in Christianity. In Chaka he could explore it in a pre-Christian, pre-Western setting for its own inherent ethical measurements: the role of botho in African leadership. This pre-era is specifically marked as such by Mofolo in a further deviation from the original writings by Sekese. Mofolo, through Chaka, suggests that the era in which the latter lived, in which he transgressed the values of African tradition, is coming to an end: "You are killing me in the hope that you will be kings when I am dead, whereas you are wrong, that is not the way it will be because umlungu, the white man, is coming, and it is he who will rule you, and you will be his servants" (167).

In this sense then the "purpose of the novel" could have been to formulate the ethical values and morals of a coherent community before it came in contact with Christianity. With this I am not saying that the novel is free of Christianity. But not acknowledging the important coherent tracks of an African worldview in the original Sesotho is doing a great injustice to Mofolo. Reading him as little more than the missionaries' Christian puppet is to deny him his brilliant artistry, his wide-ranging and informed intellect, his philosophical disposition, but above all, his genius as one of the great writers of Africa.

\section{Works Cited}

Agar, M. "The Biculture in Bilingual." Language in Society 20 (1991): 167-81.

Attwell, David. "Mofolo's Chaka and the Bambatha Rebellion." Research in African Literatures 18.1 (1987): $52-70$.

Berglund, Axel-Ivar. Zulu Thought-Patterns and Symbolism. London: C. Hurst \& Co., 1976.

Brand, Gerrit. Speaking of a Fabulous Ghost: In Search of Theological Criteria, with Special Reference to the Debate on Salvation in African Christian Theology. Contributions to Philosophical Theology Vol. 7. Frankfurt am Main: Peter Lang, 2002.

Comaroff, John L. \& Jean Comaroff. Of Revelation and Revolution. Volume One. Chicago and London: The U of Chicago P, 1991.

Chaka, Limakatso. "Land, botho and identity in Thomas Mofolo's Novels." Tydskrif vir Letterkunde 53.2 (2016): 63-86.

Du Plessis, J. A., Gildenhuys, J. G. \& J. J. Moiloa. Bukantswe Ya Maleme-Pedi-Sesotho-Seafrikanse. Pretoria: J.L. van Schaik, n.d.

Gérard, Albert S. Four African Literatures: Xhosa, Sotho, Zulu, Amharic. Berkeley: U of California P, 1971.

Hermans, Theo. "Introduction: Translation Studies and a New Paradigm". The Manipulation of Literature: Studies in Literary Translation. Ed. Theo Hermans. New York: St Martin's Press, 1985. 7-15.

Kunene, Daniel P. “The Works of Thomas Mofolo: Summaries and Critiques”. Occasional Papers Series. 4 Jan 1970. 15 Feb. 2015. Los Angeles: U of California (James S. Coleman African Studies Center UCLA). < http://escholarship.org/uc/item/22w2c729>.

. Thomas Mofolo and the Emergence of Written Sesotho Prose. Braamfontein: Ravan Press, 1989.

Malaba, Mbongeni. “The Legacy of Thomas Mofolo's Chaka”. English in Africa 13.1 (1986): 61-71.

Mofolo, Thomas. Chaka. [Lesotho Orthography]. Morija: Morija Sesuto Book Depot, 1957 [1925]. 
Chaka: A New Translation of the Famous Novel. Trans. Daniel P. Kunene. London: Heinemann, 1981. Moeti oa Bochabela. Morija: Sesuto Book Depot, 1907.

. Pitseng. Morija: Morija Sesuto Book Depot, 1910.

Ngubane, Harriet. Body and Mind in Zulu Medicine: An Ethnography of Health and Disease in Nyuswa-Zulu Thought and Practice. London: Academic Press, 1977. 